\title{
Yö- ja kokoaikalaiduntamisen vaikutus lehmien syöntiin ja maitotuotokseen
}

\author{
Auvo Sairanen ${ }^{1)}$, Elina Juutinen ${ }^{1)}$, Sari Kajava ${ }^{2)}$ \\ ${ }^{1)}$ Maa- ja elintarviketalouden tutkimuskeskus, Kotieläintuotannon tutkimus, Halolantie 31 A, 71750 \\ Maaninka, etunimi.sukunimi@mtt.fi \\ ${ }^{2)}$ Itä-Suomen yliopisto, Biologian laitos, PL 111,80101 Joensuu, skajava@student.uef.fi
}

\section{Tiivistelmä}

Suomen olosuhteissa kokoaikalaiduntamisen toteutus on haastavaa karjakoon kasvaessa. Laitumen- ja vihantaviljan osuus ProTuotos-lehmien rehunkulutuksesta vuonna 2010 oli 6,3 \% kuiva-aineesta (Huhtamäki 2011). Haasteellisuus on seurausta nurmen vaihtelevasta kasvunopeudesta laidunkauden aikana sekä navetan läheisyydessä sijaitsevien peltolohkojen riittämättömästä alasta tarpeeseen verrattuna. Pihattonavetassa väkirehu voidaan kokoaikalaiduntavilla lehmillä jakaa vain lypsyn yhteydessä ja kerta-annos voi nousta suureksi. Lisäksi väkirehun jako asemalla on yleensä käsityötä. Osa-aikalaidunnus tuo ratkaisun näihin ongelmiin. Osa-aikaisuuden astetta voidaan säätää käytettävissä olevan peltoalan mukaan. Lehmät saavat väkirehun sisälläoloaikana kioskista, lypsyrobotilta tai seosrehun mukana, jolloin väkirehunjako-ongelma lypsyasemalla poistuu. Osa-aikalaiduntamisessa laitumen osuus ruokinnassa on alkukesällä suuri ja nurmen kasvun hiipuessa osuutta pienennetään.

Yö- ja kokoaikalaiduntamisen vaikutusta lypsylehmien syöntiin ja maitotuotokseen tutkittiin laidunkokeessa kesällä 2011. Ennen koetta lehmät olivat 12 vrk yölaiduntajia ja niiden väkirehuruokinta oli sama. Kokeessa oli 36 lypsylehmää ja muuttujina oli laidunnusaika (osa-aikainen, OL tai kokoaikalaidun, KL) sekä kaksi väkirehun raakavalkuaispitoisuus (matala MRV 153 g/kg ka, korkea KRV 197 g/kg ka). Kokeessa oli kaksi jaksoa ja eläin oli samalla laidunkäsittelyllä koko kokeen ajan, mutta valkuaiskäsittely muuttui jaksojen välissä. OL-ryhmä laidunsi ilta- ja aamulypsyn välisen ajan $12,5 \mathrm{~h} / \mathrm{vrk}$ ja ne saivat vapaasti säilörehua navetassa päivällä 9,5 h/vrk eli karkearehua oli saatavilla noin $22 \mathrm{~h} / \mathrm{vrk}$. KL-ryhmän laidunnusajaksi muodostui 18,5 h/vrk. Väkirehuannos oli koko kokeen ajan 9 kg/vrk. KL-ryhmä sai väkirehun kahteen annokseen jaettuna lypsyasemalta ja OL-ryhmä puolet päivittäisestä väkirehuannoksesta aamulypsyn aikana lypsyasemalta ja puolet väkirehukioskista päivän aikana. Laidunalaksi oli mitoitettu OL-ryhmälle 0,6 aaria/lehmä/vrk ja KL-ryhmälle 1,0 aaria/lehmä/vrk. Laitumen nurmimassa mitattiin kehikkomittausmenetelmällä. Laidunruohon syönti arvioitiin lypsylehmien maidontuotantoon tarvittavan energian tarpeen ja sisäruokinnan energiansaannin erotuksena. Lisäksi laidunnuskäyttäytymistä tarkkailtiin suoraseurannalla.

Säilörehun syöntimäärä sisällä oli suuri, $8,9 \mathrm{~kg} \mathrm{ka} / \mathrm{vrk}$. Osa-aikalaiduntajilla laidunrehun laskennallinen osuus koko dieetistä jäi siten suhteellisen pieneksi. Laidunrehun laatu oli vähintään kohtuullista ja laidunolosuhteet eivät olleet poikkeuksellisen vaativat. OL-ryhmän laskennallinen laidunsyönti oli pieni ottaen huomioon sekä laidunajan että laitumen syöntiin käytetyn ajan. Lehmät käyttivät lypsyjen välillä laiduntamiseen aikaa noin neljä tuntia vuorokaudenajasta tai laidunaikaryhmästä riippumatta. Samasta yökaudella syöntiin käytetystä ajasta huolimatta OL-lehmien kokonaissyöntimäärä oli KL-lehmiä pienempi eli syöntinopeus tuntia kohti oli osa-aikalaiduntajilla todella pieni $(0,7 \mathrm{~kg} \mathrm{ka} / \mathrm{h})$. Kokeessa ei mitattu laitumen todellista syöntiä, mutta laskennallinen syönti ja visuaalinen arvio laitumesta tukevat havaintoa pienestä laidunrehun syöntimäärästä OL-ryhmässä.

Tässä kokeessa kokoaikalaiduntajien maitomäärä oli sama kuin osa-aikalaiduntajilla. Kokoaikalaiduntaminen laski maidon rasvapitoisuutta ja samalla kokoaikalaiduntajien energiakorjattu maitotuotos jäi 1,1 $\mathrm{kg} / \mathrm{vrk}$ osa-aikalaiduntajia pienemmäksi. Laidunrehun laskennallinen OIV-arvo on korkea, mikä näkyi myös käytännössä lisävalkuaisruokinnan heikkona tuotosvasteena. Tämä tulos tukee aikaisempia lisävalkuaiskokeita laitumella. Yhdysvaikutusta laidunnusajan (OL vs. KL) ja valkuaisvasteen välillä ei ollut, mikä on hieman yllättävää. Osa-aikalaiduntajilla säilörehun osuus ruokinnassa on huomattava ja olisi voinut olettaa lisävalkuaisesta saatavan hyödyn olevan osa-aikalaiduntajilla lähellä säilörehudieettien vasteita. Lehmät vähentävät laidunrehun syöntiä huomattavasti, mikäli tarjolla on säilörehua sisällä vapaasti. Laidunrehun hyväksikäyttöä saattaa lisätä laidunalan rajaaminen pienemmäksi nykyisiin suosituksiin verrattuna tai sisällä tarjotun säilörehun rajoittaminen.

Asiasanat: Laidun, laiduntaminen, lypsylehmä, valkuaispitoisuus, väkirehu 


\section{Johdanto}

Suomen keskikarjakoko on lisääntynyt viimeisten 15 vuoden aikana keskimäärin 1,1 lehmää vuodessa ja oli vuonna 201029 lehmää/tila (Nokka 2011). Karjakoon on otaksuttu tulevaisuudessa kasvavan tätä nopeammin. Lypsylehmien laiduntaminen puolestaan on tasaisesti vähentynyt ja laitumen- ja vihantaviljan osuus lehmien kuiva-aineensaannista on tällä hetkellä vain noin 6,3 \% (Huhtamäki 2011). Laitumen osuuden väheneminen on huolestuttavaa. Laidun ei ole välttämätöntä lehmien ruokinnan kannalta ajateltuna, mutta laiduntavien lehmien näkyvyydellä on kuitenkin huomattava merkitys ihmisten mielikuvaan maidontuotannosta ja maaseudusta ylipäätään. Pitkällä tähtäimellä ajateltuna maidontuotantoelinkeinolla ei olisi varaa laiduntamisen häviämisen mukanaan tuomaan imagotappioon.

Laiduntaminen mielletään myös osaksi lehmien hyvinvointia. Tämä näkyy lainsäädännössä ja suunnitteilla olevien maitotalouden tukitoimenpiteiden muodossa. Tukea kanavoidaan enenevissä määrin eläinten hyvinvoinnista huolehtimiseen ja tässä yhteydessä laiduntamisen merkitys korostuu. Tutkimustulokset sinällään eivät todista laiduntamista yksioikoisesti sisäruokintaa paremmaksi vaihtoehdoksi (Virkajärvi ym. 2004, Chapinal ym. 2010). Pääasiallisesti laiduntamisen oletetaan vaikuttavan positiivisesti lypsykarjan hyvinvointiin. Laiduntamisen on havaittu parantavan lehmien jalkaterveyttä (Rodriguez-Lainz ym. 1999, Wells ym. 1999, Haskell ym. 2006, Hernandez-Mendo ym. 2007, Olmos ym. 2009) sekä utareterveyttä (Washburn ym. 2002, White ym. 2002). Tanskassa laiduntamisen on havaittu vähentävän lehmien kuolleisuutta (Burow ym. 2011) sekä kohtutulehduksien määrää (Bruun ym. 2002). Laiduntamisen terveysvaikutukset eivät kuitenkaan ole yksiselitteisiä, koska joissain tutkimuksissa laiduntamisen on havaittu heikentävän lehmien jalkaterveyttä (Holzhauer ym. 2006) ja huonontavan karjan kuntoluokitusta (Washburn ym. 2002).

Laidunrehu on oikein tuotettuna halvinta rehua lypsylehmille, koska säilörehun korjuu- ja säilöntäkustannukset jäävät pois (Seppälä ym. 2006). Laidunrehun ruokinnallinen arvo on korkea sekä energia että valkuaispitoisuuden osalta (MTT 2011, Sairanen 2006). Laidunruokinnalla voidaan käyttää säilörehuruokintaa pienempää väkirehun valkuaispitoisuutta. Laidunrehun edullisuus ei kuitenkaan ole itsestäänselvyys. Virheet laidunkierron mitoituksessa tai ruokinnansuunnittelussa kostautuvat alentuneena maitotuotoksena ja tällaisessa tilanteessa laidunrehu menettää kannattavuusetunsa.

Kokoaikalaiduntavien lehmien maitotuotos voidaan pitää korkeana alle $40 \%$ väkirehuosuudella dieetin kuiva-aineesta. Korkeatuottoinen lehmä syö kuiva-ainetta yli $25 \mathrm{~kg} / \mathrm{vrk}$ ja väkirehun määrä nousee yli 12 kuiva-aine kiloon päivässä. Pihattonavetassa väkirehu voidaan kokoaikalaiduntavilla lehmillä jakaa vain lypsyn yhteydessä ja kerta-annos nousee tällöin suureksi. Lisäksi väkirehun jako asemalla on lisäksi yleensä käsityötä, joten ongelmat väkirehun jaossa aiheuttavat huomattavaa ongelmaa kokoaikalaiduntavilla lehmillä.

Osa-aikalaiduntaminen sopii hyvin Suomen olosuhteisiin. Lehmät saavat väkirehua sisälläoloaikana kioskista, lypsyrobotilta tai seosrehun mukana, jolloin väkirehunjako-ongelma lypsyasemalla poistuu. Nurmen kasvu vaihtelee huomattavan paljon laidunkauden sisällä, mikä aiheuttaa vaikeuksia laitumen mitoituksen kanssa. Osa-aikalaidun ja säilörehun käyttö navetassa puskuriruokintana poistaa nurmen kasvun vaihtelusta aiheutuvan laidunalan mitoitusongelman.

Aikaisemmissa kotimaisissa laidunkokeissa on verrattu sisäruokintaa ja osa-aikalaiduntamista (Sairanen ym. 2006), mutta vertailua kokoaikalaitumen ja osa-aikalaitumen kesken ei ole Suomessa tehty. Näissä kahdessa kokeessa osa-aikalaidunryhmän lehmät lypsivät enemmän kuin sisäruokinnassa olleet eläimet. Joissakin ulkomaisissa laidunkokeissa sekä osa- että kokoaikalaidunryhmien lehmät ovat tuottaneet vähemmän maitoa verrattuna sisäruokintaan. Käytännön havainnot Suomessa, mm. meijereiden maidon vastaanottotilastot, antavat vihjeitä laidunruokinnan ongelmista.

Tämän kokeen tarkoituksena on mitata kokoaikalaiduntavien lypsylehmien tuotospotentiaalia osaaikalaiduntaviin verrattuna sekä arvioida osa-aikalaitumen vaatimaa laidunmitoitusta. Lisäksi käsittelynä kokeessa oli väkirehun raakavalkuaispitoisuus. Koe suoritettiin MTT Maaningan toimipisteessä osana Nykyaikainen navettateknologia -hanketta (NYT), jonka rahoittajana toimivat Pohjois-Savon liitto ja PohjoisSavon ELY keskus (Euroopan sosiaalirahasto).

\section{Materiaalit ja menetelmät}

Koe suoritettiin välillä 30.6. - 10.8.2011. Koejäseninä käytettiin laidunaikaa (osa-aikainen; OL ja kokoaikalaidun; KL) sekä kahta väkirehun raakavalkuaispitoisuutta (matala MRV 153 g/kg ka, korkea KRV 197 g/kg ka). Koeasetelmana oli kaksijaksoinen cross overin (valkuaismuuttuja) ja satunnaistettujen lohkojen (laidun- 
aikamuuttuja) yhdistelmä. Yhden koejakson pituus oli 15 päivää. Lisäksi lehmien lähtötason säilörehun syönti, maitotuotos ja maidon pitoisuudet ennen koetta on huomioitu 12 päivää kestäneen mittausjakson viimeisiltä viideltä päivältä lukuun ottamatta maitonäytteitä, jotka otettiin vain kahtena peräkkäisenä päivänä (=kovariaattijakso).

Kokeessa oli yhteensä 36 Ayshire- tai Holstein lypsylehmää, joista 17 oli ensikkoa ja 19 useamman kerran poikinutta lehmää. Kokeen alkaessa eläinten maitotuotos oli $31,9 \pm 6,4 \mathrm{~kg} / \mathrm{vrk}$ ja poikimisesta oli kulunut $101 \pm 32$ päivää. Ennen koetta olleen kovariaattijakson aikana kaikki lehmät laidunsivat vain yöaikaan $(12,5 \mathrm{~h} / \mathrm{vrk})$ ja saivat karkearehua vapaasti osastossa $(9,5 \mathrm{~h} / \mathrm{vrk})$. Kovariaattijaksolla lehmät saivat $9 \mathrm{~kg} / \mathrm{vrk}$ ohraa/rypsitiivistettä ja ohran ja rypsitiivisteen määrällä painotettu raakavalkuaispitoisuus oli $177 \mathrm{~g} / \mathrm{kg} \mathrm{ka}$.

Kovariaattijakson jälkeen lehmät jaettiin pareiksi poikimakerran, poikimisesta kuluneen ajan ja maitotuotoksen perusteella. Parin toinen eläin siirtyi osa-aika- $(n=18)$ ja toinen kokoaikalaiduntajaksi $(n=18)$. Laidunkäsittely oli sama koko kokeen ajan. Parit satunnaistettiin väkirehun valkuaiskäsittelyille. OL -ryhmä laidunsi samalla tavoin kuin kovariaattijaksolla. KL -ryhmä laidunsi vuorokauden ympäri lukuun ottamatta kaksi kertaa päivässä tapahtunutta lypsyä (yht. 5,5 h/vrk). OL- ja KL-ryhmä laidunsivat samalla lohkolla, mutta niiden välissä oli kevyt aita (=laidunkaista). Eläimet saivat uuden laidunkaistan joka päivä ja laidunalaa mitoitettiin 1 aari/KL-lehmä/vrk ja 0,6 aaria/OL-lehmä/vrk.

Kaikkien lehmien väkirehuannos oli koko kokeen ajan $9 \mathrm{~kg} / \mathrm{vrk}$ ja väkirehuna oli ohraa ja rypsitiivistettä. OL-ryhmä sai aamulypsyllä 4,5 kg väkirehua ja 4,5 kg päivän aikana väkirehukioskista kahteen annokseen jaettuna. KL-ryhmä sai 4,5 kg annoksen väkirehua aamu- ja iltalypsyn yhteydessä lypsyasemalla. Osaaikalaiduntajat saivat sisälläoloaikana $(9,5 \mathrm{~h} / \mathrm{vrk})$ vapaasti ensimmäisen sadon säilörehua automaattisesti säilörehun syöntiä mittaavista kupeista (Insentec B.V., Marknesse).

Laidunruohon alkumassa ennen laiduntamista mitattiin päivittäin aamulla kahdeksana peräkkäisenä päivänä jakson lopussa. Laidunlohkosta leikattiin satunnaisesti neljän kehikon $(20$ x $50 \mathrm{~cm})$ alalta kasvusto 6 $\mathrm{cm}: n$ korkeuteen. Leikatut laidunnäytteet punnittiin ja kuivatettiin $60^{\circ} \mathrm{C}: \mathrm{ssa} 48 \mathrm{~h}$ ja näytteet yhdistettiin jaksojen lopussa. Säilörehunäytteet otettiin viitenä viimeisenä päivänä jakson lopussa ja näytteet yhdistettiin rehuittain ja jaksoittain. Näytteistä analysoitiin tuhka, orgaanisen aineen sellulaasiliukoisuus, raakavalkuainen, NDF, pH, haihtuvat rasvahapot, maitohappo, ammoniumtyppi ja liukoinen typpi. Säilörehun kuiva-aine korjattiin Huidan ym. (1986) mukaan haihtuvien rasvahappojen osalta. Väkirehusta määritettiin kuiva-aine, raakavalkuainen, raakarasva ja raakakuitu MTT:n Kotieläintuotannon tutkimuksen laboratoriossa. Laidunruohosta tehtiin samat analyysit lukuun ottamatta rehun säilönnällistä laatua. Maitomäärät mitattiin päivittäin, mutta laskennassa käytettiin jaksojen viimeisten viiden viimeisen päivän keskiarvoa. Maidon pitoisuudet määritettiin kahtena peräkkäisenä päivänä jokaisen jakson lopussa.

Laitumen syönti laskettiin lypsylehmien energian tarpeen ja sisäruokinnan energiansaannin erotuksena (MTT 2010). Laskennassa otettiin huomioon ylläpitoon tarvittava energiamäärä laskien eläimen keskimääräinen elopaino. Elopaino mitattiin väkirehukioskeissa olevilla vaaoilla. Elopainot mitattiin OL-ryhmän eläimiltä koko kokeen ajalta ja KL-ryhmältä kovariaatin ja kokeen jälkeisen viiden viimeisen päivän perusteella. Elopainon muutosta ei voitu ottaa huomioon energiatarpeen muutoksen laskennassa, koska KLryhmän punnituksia ei ollut kokeen ajalta käytettävissä.

Suoraseurannat tehtiin 19.7. - 21.7.2011 (1. jakso) ja 8.8. - 10.8.2011 (2. jakso) välisenä aikana. Seuranta aloitettiin klo 12.00 ja sitä jatkettiin yhtäjaksoisesti $48 \mathrm{~h}$ pois lukien lypsyajat. Suoran käyttäytymisseurannan otantamenetelmänä käytettiin scan sampling- menetelmää ja tiedonkeruumenetelmänä hetkellistä seurantaa (instantaneous sampling) 10 minuutin havaintovälein (Martin \& Bateson 2007). Tarkkailuun osallistui viisi tarkkailijaa (kerralla yksi tarkkailija/lauma) ja keskimääräinen tarkkailuperiodi kesti neljä tuntia/hlö. Tarkkailut suoritettiin pellolla olevista traktoreista. Päiväaikaan tarkkailijoita oli vain yksi, koska ainoastaan kokoaikalaiduntajat olivat tuolloin laitumella. Käyttäytymisluokkien tunnistamista harjoiteltiin ryhmässä etukäteen. Öisin tarkkailijoiden apuvälineinä käytettiin taskulamppuja.

Tulokset laskettiin SAS 9.2:n Mixed-proseduuria käyttäen. Tilastomallissa oli mukana ennen koetta mitattu muuttujan kovariaattiarvo, eläin, jakso, laidunaika (OL- ja KL), lisävalkuaistaso (MRV, KRV) sekä laidunajan ja valkuaistason yhdysvaikutus (Laidun*RV). Laidunajan suhteen malli oli toistettujen mittausten koe, jossa jakso oli toistotekijä. 
Taulukko 1. Rehujen kemiallinen koostumus ja rehuarvot

\begin{tabular}{|c|c|c|c|c|c|c|}
\hline & \multirow{2}{*}{\multicolumn{2}{|c|}{ Säilörehu }} & & & & \\
\hline & & & \multicolumn{2}{|c|}{ Laidunrehu } & \multirow[t]{2}{*}{ Ohra } & \multirow[t]{2}{*}{ Rypsi } \\
\hline & 1. jakso & 2. jakso & 1. jakso & 2. jakso & & \\
\hline Laitumen massa kg ka/ha ${ }^{1}$ & & & $2234 \pm 235$ & $2614 \pm 669$ & & \\
\hline Kuiva-aine $\mathrm{g} / \mathrm{kg} \mathrm{ka}$ & 219 & 210 & 160 & 147 & 870 & 880 \\
\hline $\mathrm{pH}$ & 4,19 & 4,07 & & & & \\
\hline \multicolumn{7}{|l|}{ Kuiva-aineessa, g/kg } \\
\hline Tuhka & 88,4 & 90,0 & 104 & 116 & 24,9 & 72,4 \\
\hline Raakavalkuainen & 175 & 172 & 241 & 238 & 115 & 332 \\
\hline Neutraalidetergenttikuitu & 556 & 552 & 548 & 526 & 198 & 302 \\
\hline Maitohappo & 33,7 & 36,9 & & & & \\
\hline VFA yht. & 8,37 & 9,55 & & & & \\
\hline Ammoniumtyppi, g/kg N & 57,3 & 67,1 & & & & \\
\hline Liukoinentyppi, g/kg N & 690 & 674 & & & & \\
\hline \multicolumn{7}{|l|}{ Rehuarvot } \\
\hline D-arvo, g/kg ka & 674 & 676 & 701 & 671 & & \\
\hline $\mathrm{ME}, \mathrm{MJ} / \mathrm{kg} \mathrm{ka}$ & 10,8 & 10,8 & 11,2 & 10,7 & 13,2 & 11,0 \\
\hline OIV, g/kg ka & 84,3 & 84,2 & 103 & 99,4 & 96,8 & 114 \\
\hline $\mathrm{PVT}, \mathrm{g} / \mathrm{kg} \mathrm{ka}$ & 49,8 & 47,7 & 93,9 & 95,4 & $-30,8$ & 171 \\
\hline
\end{tabular}

${ }^{1}$ Määritetty kehikkomittausmenetelmällä 6 cm sänkikorkeuteen.

\section{Tulokset ja tulosten tarkastelu}

Sääolosuhteet kokeen aikana eivät olleet mitenkään poikkeuksellisia. Jakson 1 aikana hellepäiviä oli 5 kpl (lpt yli $25^{\circ} \mathrm{C}$ ) ja sadepäiviä $8 \mathrm{kpl}$ (sadesumma $118 \mathrm{~mm} / 15 \mathrm{vrk}$ ). Jakso 2 oli viileämpi (hellepäiviä $1 \mathrm{kpl}$ ) ja kuivempi (sadesumma $34 \mathrm{~mm} / 15$ vrk). Tilastotestin mukaan maitotuotoksessa ei ollut yhdysvaikutusta jakson ja laidunajan välillä. Laidunkaudella kuuma ja kostea sää voi altistaa lehmät lämpöstressille, mikä puolestaan voi alentaa maitotuotosta ja maidon laatua (Laitinen 2011). Tämän kokeen mukaisissa olosuhteissa maitotuotoksen laskua ei kokoaikalaiduntavilla lehmillä esiintynyt verrattuna päivällä verhoseinänavetassa pidettyyn ryhmään.

Laitumen keskimääräinen D-arvo oli poikkeuksellisen huono NIR-analyysien (Valio) perusteella (668 g/kg ka). Ensimmäisen sadon säilörehun D-arvo oli molempien jaksojen keskiarvona 650 g/kg ka. Säilörehut olivat säilyneet hyvin säilörehun pH:n, maitohapon, VFA:n ja ammoniumtypen määrän perusteella. Ainoastaan liukoisen typen määrä typen kokonaismäärästä oli hieman suosituksia korkeampi. Sellulaasiliukoisuuden perusteella määritetyt laidunrehun energia-arvot olivat jonkin verran korkeampia ja ensimmäisen jakson laidunrehun osalta vastasivat kohtuullisen hyvää laidunta (Taulukko 1). Toisen jakson aikana laidunrehun energia-arvo oli samaa tasoa säilörehun kanssa. Laidunmassa-arvion ja visuaalisesti arvioituun laitumen kasvuasteeseen verrattuna laidunrehun energia-arvot ovat kuitenkin yllättävän matalia. Hyvälaatuisen laitumen kuiva-ainemassa on suosituksen mukaan välillä 2000 - $3000 \mathrm{~kg} \mathrm{ka/ha.} \mathrm{Hieman} \mathrm{matalaa} \mathrm{energia-arvoa} \mathrm{lukuun}$ ottamatta laidunolosuhteet eivät olleet tässä kokeessa tuotosta rajoittavia tekijöitä.

Aikaisemmassa osa-aikalaidunkokeessa (Sairanen ym. 2006) laidunrehun käyttö dieetin osana lisäsi maitotuotosta säilörehudieettiin verrattuna, kun vertailuryhmien väkirehumäärät olivat samat. Maitotuotoksen lisääntyminen on ollut seurausta laidunrehun paremmasta ruokinnallisesta arvosta säilörehuun verrattuna. Osa-aikalaiduntaminen ei ilmeisesti vähentänyt lehmien kokonaiskuiva-ainesyöntiä, joten laidundieetin parantunut karkearehun energia- ja valkuaisarvo ovat nostaneet maitotuotosta. Näissä aikaisemmissa kokeissa maitotuotos on lisääntynyt laidunajan lisääntyessä.

Tässä kokeessa kokoaikalaiduntajien maitomäärä oli sama kuin säilörehua saaneilla lehmillä (Taulukko 2). Eli laidunajan lisääminen puolesta vuorokaudesta täyteen vuorokauteen ei tuonut enää tuotannollista 
etua. Jaksolla 1. laitumen rehuarvo oli säilörehua korkeampi, mutta sääolosuhteet olivat jaksoon kaksi verrattuna vaativammat. Laitumen rehuarvo ja sääolosuhteet ilmeisesti kompensoivat toisensa ja maitotuotokset molemmilla jaksoilla olivat kokoaikalaidunryhmälle samat. Tulosten perusteella voidaan todeta, että samaa väkirehumäärää käyttämällä laidunruokinta ei vähennä maitotuotosta säilörehuruokintaan verrattuna. Käytännössä väkirehumäärä tulee säätää karkearehun sulavuuden mukaan. Näin ollen väkirehumäärät laitumella ja sisäruokinnassa eivät ole samat, koska laitumen sulavuus on yleensä säilörehua parempi. Tällöin vertailu ryhmien välillä mutkistuu huomattavasti. Tämän ja aikaisempien laidunkokeiden perusteella laidunruokinta on osoittautunut tuotospotentiaaliltaan vertailukelpoiseksi säilörehuruokinnan kanssa.

Kokoaikalaiduntaminen laski maidon rasvapitoisuutta ja samalla KL-lehmien energiakorjattumaitotuotos jäi 1,1 kg OL-lehmien pienemmäksi. Tässä tapauksessa kokoaikalaiduntajien maitotili jäi hieman osaaikalaiduntajia pienemmäksi. Maidon rasvasynteesi vaatii energiaa, joten rasvapitoisuuden lasku sinällään parantaa kokoaikalaiduntaneiden lehmien energiatasetta osa-aikalaiduntajiin nähden. Energiataseella on merkitystä esimerkiksi lehmien hedelmällisyyteen.

Väkirehun valkuaispitoisuudesta saatava tuotoslisäys oli matala $(0,1 \mathrm{~kg}$ maitoa per $10 \mathrm{~g} / \mathrm{kg}$ ka väkirehun rv). Tämä on samaa linjaa aikaisempien laitumen lisävalkuaiskokeiden kanssa. Yhdysvaikutusta laidunnusajan (OL vs. KL) ja valkuaisvasteen välillä ei ollut, mikä on hieman yllättävää. Osa-aikalaiduntajilla säilörehun osuus ruokinnassa on huomattava ja olisi voinut olettaa lisävalkuaisesta saatavan hyödyn olevan OLlehmillä lähellä säilörehudieettien vasteita. Maidon ureapitoisuuksien perusteella ruokinnat ovat olleet suunnitellun mukaisia. Laskennallisesti laitumen OIV -arvo on korkea ja tämä näkyy myös mitatuissa maitotuotoksissa. Sekä tämän kokeen, että aikaisempien laidunkokeiden (Sairanen julkaisematon) tulosten perusteella laidunruokinnassa voidaan käyttää sisäruokintaa pienempää väkirehun valkuaispitoisuutta.

Taulukko 2. Laidunnusajan ja väkirehun valkuaispitoisuuden vaikutus lehmien tuotoksiin ja syöntiin

\begin{tabular}{lccccccccc} 
& \multicolumn{7}{c}{ Osa-aikalaidun } & \multicolumn{7}{c}{ Kokoaikalaidun } & & Laidun & RV & Laidun*RV \\
\hline & MRV & KRV & sem & MRV & KRV & sem & & & \\
\hline \hline Maitotuotos, kg/pv & 31,8 & 32,4 & 0,44 & 31,9 & 32,2 & 0,41 & & o & \\
ekm, kg/pv & 31,3 & 31,9 & 0,64 & 30,3 & 30,7 & 0,6 & & $*$ & \\
Maidon koostumus, g/kg & & & & & & & & & \\
$\quad$ Rasva & 4,03 & 4,03 & 0,08 & 3,71 & 3,72 & 0,08 & $* *$ & & \\
$\quad$ Valkuainen & 3,27 & 3,28 & 0,04 & 3,21 & 3,23 & 0,04 & & & \\
Urea mg/dl & 30,4 & 33,9 & 1,23 & 28,4 & 34 & 1,27 & & $* * *$ & \multirow{2}{*}{ o } \\
Syönti, kg ka/pv & & & & & & & & & \\
$\quad$ Säilörehu & 8,9 & 9,1 & 0,25 & & & & 2 & & 2 \\
$\quad$ Laidun ${ }^{1}$ & 2,5 & 3,3 & 0,47 & 10,2 & 10,9 & 0,46 & $* * *$ & & \\
$\quad$ Väkirehu & 7,75 & 7,7 & 0,05 & 7,79 & 7,72 & 0,05 & & & \\
$\quad$ Kokonaissyönti & 19,15 & 20,1 & & 17,99 & 18,62 & & 2 & 2 & 2 \\
\hline
\end{tabular}

${ }^{\top}$ Laitumen syönti laskettu maidon energiamäärän ja syödyn väkirehun- ja säilörehun energiamäärän erotuksena ottaen huomioon laskennassa eläimen elopaino

${ }^{2}$ Ei laskettu

MRV, KRV= väkirehun raakavalkuaispitoisuus $153 \mathrm{~g} / \mathrm{kg} \mathrm{ka}, 197 \mathrm{~g} / \mathrm{kg} \mathrm{ka}, \mathrm{RV}=$ väkirehun RV sem $=$ keskivirhe. Tilastolliset merkitsevyydet $* * *(\mathrm{P}<0,001), * *(\mathrm{P}<0,01), *(\mathrm{P}<0,05)$ ja o $(\mathrm{P}<0,10)$

Säilörehun syöntimäärä oli OL-lehmillä suuri $8,9 \mathrm{~kg} \mathrm{ka} / \mathrm{vrk}$. Osa-aikalaiduntajilla laidunrehun laskennallinen osuus koko dieetistä jäi suhteellisen pieneksi. Laidunrehun laatu oli vähintään kohtuullista ja laidunolosuhteet eivät olleet poikkeuksellisen vaativat. OL-ryhmän laskennallinen laidunsyönti oli matala huomioon ottaen sekä laidunajan, että laitumen syöntiin käytetyn ajan. Lehmät käyttivät lypsyjen välillä laiduntamiseen aikaa noin neljä tuntia vuorokaudenajasta tai laidunaikaryhmästä riippumatta. Samasta yökaudella syöntiin käytetystä ajasta huolimatta OL-lehmien kokonaissyöntimäärä oli KL-lehmiä pienempi eli syöntinopeus tuntia kohti oli OL-lehmillä todella pieni $(0,7 \mathrm{~kg} \mathrm{ka} / \mathrm{h})$. Sisäruokintakokeessa syöntinopeudeksi on mitattu 4 
$\mathrm{kg} \mathrm{ka/h}$ (julkaisematon). Kokeessa ei mitattu laitumen todellista syöntiä, mutta visuaalinen arvio laitumesta tukee havaintoa pienestä laidunrehun syöntimäärästä OL-ryhmässä.

Lehmien syöntiaikoja tarkasteltaessa päiväsyöntiaika oli molemmilla laidunryhmillä ja molemmilla jaksoilla aina noin neljä tuntia. Elokuun tarkkailujaksolla yökauden syöntiaika väheni molemmilla ryhmillä neljästä tunnista kolmeen tuntiin. Pimeys ei estä lehmien syöntiä, mutta kuitenkin vähentää sitä. Yön pimeinä tunteina (=käyttäytymistarkkailussa tarvittiin lisävaloa) syöntiin kulutettu aika oli 9 minuuttia tuntia kohti, mikä on alle puolet valoisan ajan syöntiaktiivisuudesta. Vastaavasti päivällä syömiseen käytettiin $28 \mathrm{~min} / \mathrm{h}$ KL-ryhmässä.

Lehmien laidunhalukkuutta on aikaisemmin tutkittu (Tuomisto ym. 2010) koeasetelmalla, jossa ympärivuorokautisesti laiduntaneet lehmät saivat vapaasti valita syövätkö laidunta vai niittorehua laitumelle sijoitetusta syöttöhäkistä. Karkearehun tarjoaminen syöttöhäkistä vähensi laiduntamiseen kulunutta aikaa 7,1 tunnista 3,5 tuntiin/vrk. Kokoaikalaiduntajat käyttivät aikaa syöntiin tämän julkaisun kokeessa keskimäärin 7,3 tuntia, mikä vastaa aikaisempaa mittaustulosta. Lisäkarkearehun tarjoaminen vähentää laidunaikaa huomattavasti, mutta ei kokonaan lopeta laiduntamista. Osa-aikalaiduntamisessa laiduntamisen väheneminen tulee huomioida sekä säilörehun sisäruokintamäärää suunniteltaessa että laidunalan mitoituksessa.

Aikaisemmissa ohjeissa yölaiduntajien laidunala on mitoitettu suuremmaksi kuin päivälaiduntajien, mikä perustuu huomattavaan eroon laidunajassa. Osa-aikalaiduntajilla laidunaika ei kuitenkaan ole laitumen kokonaissyöntiä rajoittava tekijä, joten ohjetta voidaan yksinkertaistaa. Yleissääntönä osaaikalaiduntamisessa voidaan pitää vuorokauden ajankohdasta (yö/päivä) huolimatta pinta-ala mitoituksena enimmillään 0,5 aaria lehmää/vrk, kun laidun on laadultaan ja määrältään suosituksen mukaisissa rajoissa. Osa-aikalaidunta käytettäessä säilörehun määrä sisällä ei saa olla täysin vapaa, mikäli laidunrehu halutaan hyödyntää täysimääräisesti. Jos laidunrehun ja säilörehun syönti halutaan samansuuruisiksi, tulee säilörehun määrä olla noin $6 \mathrm{~kg} \mathrm{ka/vrk}$. Laskelma perustuu keskimääräiseen $21 \mathrm{~kg}$ ka päiväsyöntiin ja 10 kuivaainekilon väkirehumäärään/vrk.

\section{Johtopäätökset}

Laidunajan lisääminen osa-aikaisesta kokoaikaiseksi ei vaikuttanut maitotuotokseen, mutta vähensi maidon rasvapitoisuutta ja energiakorjattua maitotuotosta. Laidunrehun laskennallinen OIV-arvo on korkea, mikä näkyi myös käytännössä lisävalkuaisruokinnan heikkona tuotosvasteena. Laidunkaudella väkirehun valkuaispitoisuus voi olla säilörehuruokintaa matalampi. Lehmät vähentävät laidunrehun syöntiä huomattavasti, mikäli tarjolla on säilörehua sisällä vapaasti. Tilannetta voi hyödyntää joko rajaamalla laidunala pienemmäksi nykyisiin suosituksiin verrattuna tai rajoittamalla sisällä tarjotun säilörehun määrää. Suurille karjoille sopivampi vaihtoehto on laidunalan, ja mahdollisesti myös laidunajan, rajaaminen pieneksi. Laidun- ja säilörehun vuorokautinen yhteismäärä turvaa lehmille vapaan karkearehusaannin. Tässä kokeessa syöntiaika ei ollut tuotosta rajoittava tekijä. Yleissääntönä osa-aikalaiduntamisessa voidaan pitää vuorokauden ajankohdasta (yö/päivä) huolimatta alamitoituksena enimmillään 0,5 aaria lehmää/vrk, kun laidun on laadultaan ja määrältään suosituksen mukaisissa rajoissa.

\section{Kirjallisuus}

Burow, E., Thomsen, P. T., Sørensen, J. T. \& Rousing, T. 2011: The effect of grazing on cow mortality in Danish dairy herds. - Preventive Veterinary Medicine 100: 237-241.

Bruun, J., Ersbøll, A. K. \& Alban, L. 2002: Risk factors for metritis in Danish dairy cows. Preventive Veterinary Medicine 54: 179-190.

Chapinal, N., Goldhawk, C., de Passillé, A. M., von Keyserlingk, M. A. G., Weary, D. M. \& Rushen, J. 2010: Overnight access to pasture does not reduce milk production or feed intake in dairy cattle. Livestock Science 129: 104110 .

Haskell, M.J., Rennie, L.J., Bowell, V.A., Bell, M.J. \& Lawrence, A.B. 2006: Housing system, milk production, and zero-grazing effects on lameness and leg injury in dairy cows. Journal of Dairy Science 89: 4259-4266.

Hernandez-Mendo, O., von Keyserlingk, M. A. G., Veira, D. M. \& Weary, D. M. 2007: Effects of pasture on lameness in dairy cows. Journal of Dairy Science 90: 1209-1214.

Holzhauer, M., Hardenberg, C., Bartels, C.J.M. \& Frankena, K. 2006: Herd and cow level prevalence of DigitalDermatitis in The Netherlands and associated risk factors. Journal of Dairy Science 89: 580-58.

Huhtamäki T. 2011. Suullinen tiedonanto 25.5.2011. 
Huida, L., Väätäinen, H. \& Lampila, M. 1986. Comparison of dry matter contents in grass silages as determined by oven drying and gas chromatographic water analysis. Annales Agriculturae Fenniae 25: 215 - 230.

Laitinen H. 2011. Helteet koettelivat maidon laatua. Maito ja Me 4:2011: 14-15 s.

Martin, P. \& Bateson, P. 2007. Measuring Behaviour An Introductory Guide. 48 - 61 s. Cambridge University Press. Cambridge.

MTT 2011. Rehutaulukot ja ruokintasuositukset [verkkojulkaisu]. Jokioinen: MTT Maa- ja elintarviketalouden tutkimuskeskus. [viitattu 1.12.2011]. Saatavissa: http://www.mtt.fi/rehutaulukot.

Nokka S. 2011. Tuotosseurannan tulokset 2010, ProAgria Keskusten Liitto 14.4.2011 Vantaa.

Sairanen A., Khalili H., Virkajärvi P. \& Hakosalo J. 2006. Comparison of part-time grazing and indoor silage feeding on milk production. Agricultural and food science 15, 3:280-292.

Olmos, G., Boyle, L., Hanlon, A., Patton, J., Murphy J. J. \& Mee, J. F. 2009: Hoof disorders, locomotion ability and lying times of cubicle-housed compared to pasture-based dairy cows. Livestock Science 125:199-207.

Rodriguez-Lainz, A., Melendez-Retamal, P., Hird, D. W., Read, D. H. \& Walker, R. L. 1999: Farm- and host-level risk factors for papillomatous digital dermatitis in Chilean dairy cattle. Preventive Veterinary Medicine 42: 87-97

Seppälä R., Sipiläinen T., Ryhänen M., Sairanen A., Virkajärvi P., Palva R. \& Rinne M. 2006. Laidun lypsylehmien ruokinnassa - pitkän aikavälin taloustarkastelu. In: Topi Hulmi, Mari (toim.). Laajentavien karjatilojen kesäruokintavaihtoehdot: Iisalmi 19.4.2006. Suomen Nurmiyhdistyksen julkaisu 23: 18.-45 s.

Tuomisto L., Frondelius L., Mononen J., Sairanen A. 2010. Haluaako lehmä laiduntaa? Teoksessa:. Anneli Happonen (toim.) Maataloustieteenpäivät, 12.-13.1.2010. Suomen maataloustieteellisen seuran tiedote 27: 181s.

Virkajärvi P., Hakosalo J., Sairanen S., Halonen R., Mononen J., Ahola L., Kauppinen R., Lindeberg H \& Khalili H. 2004. Comparison of the effect of night-time grazing versus silage feeding on milk production and animal welfare. In: A.Lüscher, B.Jeangros, W.Kessler, O.Huguenin, M.Lobsiger, N.Millar, D.Suter. Land Use Systems in Grassland Dominated Regions.Proceedings of the 20th General Meeting of the European Grassland Federation.

Washburn, S. P., White, S. L., Green, J. T., Jr. \& Benson, G. A. 2002: Reproduction, Mastitis, and Body Condition of Seasonally Calved Holstein and Jersey Cows in Confinement or Pasture Systems. Journal of Dairy Science 85: 105111.

Wells, S. J., Garber, L. B. \& Wagner, B. A. 1999: Papillomatous digital dermatitis and associated risk factors in US dairy herds. Preventive Veterinary Medicine 38 11-24.

White, S. L., Benson, G. A., Washburn, S. P. \& Green, J. T., Jr. 2002: Milk production and economic measures in confinement or pasture systems using seasonally calved Holstein and Jersey cows. Journal of Dairy Science. 85, 62104. 